\title{
Interactive Lesson on the Cell
}

\author{
Linda Burhansstipanov ${ }^{1}$ and Lynne T. Bemis ${ }^{2}$ \\ ${ }^{1}$ Native American Cancer Research \\ ${ }^{2}$ University of Colorado Denver
}

\begin{abstract}
The purpose of this article is to explain how a basic hands-on lesson about the human cell was developed, implemented and evaluated through Genetic Education for Native Americans (GENA®) workshops.

(C)2007 Californian Journal of Health Promotion. All rights reserved.

Keywords: Native American, science education, genetic education, the human cell
\end{abstract}

\section{Introduction}

Genetic Education for Native Americans (GENA®) [R25 HG01866] was an education intervention study supported by the National Human Genome Research Institute (2006) from 1998 through 2003. The goals of GENA® were established based on Native American community needs expressed at focus groups and during individual meetings with community members in 1995-1997. Elders from Native communities expressed the need for information about genetic testing and research so that informed decisions about healthcare and participation in genetic studies could be made by Native leaders. Based upon elder Natives' guidance, the initial group for this education was Native college students. Thus, these young professionals could return to their communities and assist the elders and leaders in making decisions related to genetic research and related issues. The primary goal of GENA ${ }^{\circledR}$ was to provide culturally competent education about genetic research to Native American college and university students. The initial GENA ${ }^{\circledR}$ education study was very successful and ended in 2003. The GENA curriculum was implemented at over 20 professional meetings with over 500 participants from 1998 through 2003 and is described in other publications (Burhansstipanov, Bemis, Dignan, 2001, 2002; Burhansstipanov, Bemis, Dignan, Dukepoo, 2001; Burhansstipanov, Bemis, Kaur, Bemis, 2005; Dignan, Burhansstipanov, Bemis, 2005;
Romero, Bemis, Dignan, Burhansstipanov, 2001).

Participants included undergraduate and graduate students, community and faculty members. GENA ${ }^{\circledR}$ is team taught with a cultural representative as well as faculty from the fields of public health, molecular genetics, or classical genetics as part of each presentation. The team approach has been extremely successful as evaluated by pre- and post-tests as well as delayed assessment from $10 \%$ of participants. Assessments comparing the increased knowledge post-education as compared to preeducation have revealed a gain of knowledge $(\mathrm{p} \leq 0.001)$ for all workshops where GENA ${ }^{\circledR}$ has been presented to date (Dignan, et al., 2005). The overall level of interest in information pertaining to the human genome and genetics has been rated as extremely helpful and of need in the community. Members from other communities have expressed an interest in such programs for their own communities. Furthermore, GENA ${ }^{\circledR}$ workshops were requested by scientists working with communities who realize that community values must be considered when initiating genetic or genomic research.

The NHGRI provided supplemental funding for new GENA ${ }^{\circledR}$ objectives to be developed, implemented and evaluated during 2003 through 2005. This supplemental funding resulted in Objective 26 on models for genetic basic science 
and cultural issues; Objective 25 What is a Cell? (specifically designed as a result of Native elders request and inclusion of hands on interactive experience); objectives 27 and 28 on the HapMap Project; and, objective 29 cultural issues, facts and myths.

As of October 2005, GENA ${ }^{\circledR}$ was included within the (SACNAS) [R25 HG003200-02S1] grant. Since 2003, an average of five GENA ${ }^{\circledR}$ workshops was held each year in geographically diverse regions of the US. An Audience Response System (ARS) that uses wireless electronic keypads increased the breadth and depth of GENA ${ }^{\circledR}$ participants' knowledge, attitudes, behaviors, opinions and workshop evaluation.

\section{Background for GENA® Objective 26, "The Cell”}

The Cell GENA ${ }^{\circledR}$ objective evolved after implementing an 8 hour GENA ${ }^{\circledR}$ workshop in Bethel, Alaska in 2002. The workshop was to provide background information for tribal leaders from nearby villages to help them determine if they wanted to become involved with genetic research studies as part of an ongoing community based participatory research (CBPR) relationship with University of Alaska, Fairbanks. At the end of the GENA ${ }^{\circledR}$ workshop, a respected Alaska Native leader talked with the faculty about what he had learned. One of his comments was, "I understand the genes better now and the chromosomes, but I'm still a little confused about what is a cell." Dr. Bemis explained the cell and its relationship to chromosomes and genes. As so often happens when working with community members, the faculty learns as much if not more than the workshop participants. Clearly there was a need to create a lesson on the cell, but one that used a lot of hands on activity because such lessons result in greater learning and tend to be more fun for the participants.

With supplemental funding support from NHGRI ELSI, the authors developed GENA ${ }^{\circledR}$ objective 26, "What is a cell?" The workshop for this objective requires one hour. This objective was taught independently and in combination with other GENA ${ }^{\circledR}$ objectives. Settings included Tribal College students, Native community members, cancer professionals who work with Native communities, tribal leaders, and Native parent-children science workshops. Thus, objective 26 was implemented and evaluated in very diverse venues and with participants who had no science background as well as with those with extensive science background.

Description of GENA ${ }^{\circledR}$ objective 26. GENA ${ }^{\circledR}$ objective 26 is, "The participant will identify parts of the cell." The initial GENA ${ }^{\circledR}$ objective 26 was implemented during a Wellness and Women conference in February 2003. The objective involved interactivity throughout the objective while participants created a somatic cell using plastic jewelry bags (nucleus) and curly ribbon (chromosomes), sandwich bags (cell), beads (mitochondria), plastic air packing materials (vacuoles and golgi), plastic mesh (reticulum), liquid soap (cytoplasm). Using a donation of red blood cell rubber models (Procrit $($ )), the participants created a blood vessel (single cell layer) and those who came late to the session, were the red blood cells going through the vessel.

The content begins by describing that all humans start from germ cells, using the slide as in Figure 1. The lesson continues with explaining grown of fertilized cells into human beings using easyto-understand language. Each working group's table has a complete set of the cell materials and directions (see Appendix A). Analogies are made between the cell and common Native concepts. For example, the Tribal Council Office is compared to the nucleus because it holds all of the information about the Native village (see Figure 2). Likewise, the endoplasm reticulum is described as a way for parts of the cell to talk to one another, like a telephone. A diagram of a real cell is shown. Then the workshop participants are asked for form groups of four and rather than continue with a lecture, they are asked to create a cell (see Figure 3).

Materials needed to make the cell are placed at the center of each table. The materials include the following: small plastic jewelry bags, wire plastic covered bread ties, ribbon, scissors, 
plastic sandwich bags, plastic mesh (such as the mesh that is used for easily bruised fruits and vegetables), small bubble wrap, clear liquid soap, and small beads.

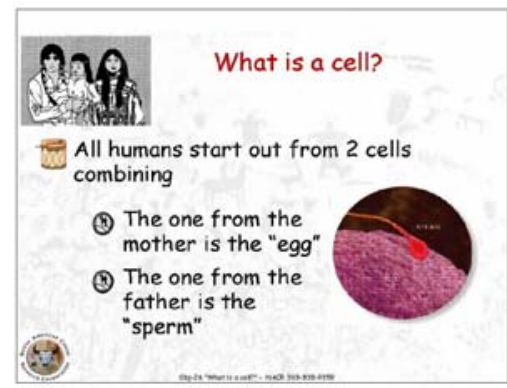

Figure 1

Excerpt from GENA ${ }^{\circledR}$ objective 26

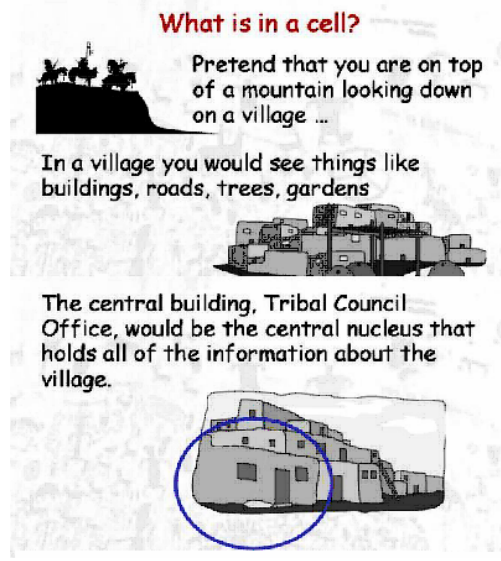

Figure 2

Examples of analogies of real life to the "cell"

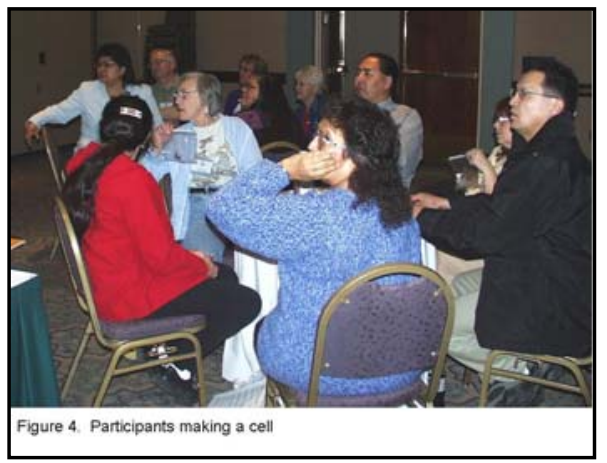

Figure 3

Participants making a cell 
The faculty goes through step-by-step using Power Point ${ }^{\circledR}$ slides to illustrate each step as shown in Appendix A as the participants assemble their cell using the sandwiches bags.

\section{Description of the Audience Response System (ARS)}

Native American Cancer Research (NACR) owns an Audience Response System (ARS). This is a computer-operated wireless keypad system that collects (a) participant demographics; (b) pre-workshop knowledge assessments; (c) opinion items; (d) postworkshop knowledge assessments; and (e) overall workshop evaluation. The system is integrated within the GENA ${ }^{\circledR}$ Power Point ${ }^{\circledR}$ slides and has the option of allowing participants to see the group's responses or to hide the responses. Demographics, opinion, and postworkshop knowledge assessment items display the results as a bar graph for the participants to see once the voting is completed for each item. The workshop participant responses are not shown for the pre-workshop knowledge items or for the workshop evaluation to reduce bias from the group. The ARS software provides multiple report formats summarized into Excel. The Excel file is transferred into SAS, SPSS, SUDAAN and other statistical analyses programs. The lesson has been successful with all groups.

\section{Findings}

Nine GENA ${ }^{\circledR}$ workshops between 2003 through 2005 included objective 26. Of these, six were combined with other GENA ${ }^{\circledR}$ objectives and only three focused on objective 26 independently. For example, the February 2003 Wellness and Women workshop held during the Native Wellness and Healing Conference was limited to objective 26 only. This was the first time the objective was implemented and the faculty wanted nothing to interfere with its evaluation.

Objective 26 was taught to 163 participants of whom most (78\%) were females and more than half $(56.3 \%)$ were American Indian or Alaska Native. More than one-third (35.6\%) had never had any previous genetic education; more than one-quarter $(27.5 \%)$ had between 1 -4 hours of genetic education; $13.7 \%$ had between 5-10 hours; and, less than one-quarter $(23.3 \%)$ had more than 10 hours of genetic education. However, even the science teachers and nurses who took part in these workshops had an enjoyable experience and showed an increase in knowledge. Objective 26 has 4 knowledge items specific to the content. The average preworkshop knowledge score for all nine workshops on these four items was $28.29 \%$. The average post-workshop knowledge score for all nine workshops on the same four items was $77.22 \%$ correct ( $\mathrm{p}$ value was $<.01$ for the increase in knowledge). The average increase from pre-test to posttest was $47.48 \%$.

Qualitative evaluation was collected for the initial workshops. Participants wrote comments such as the following:

- "I never thought I could do science. I thought only white people and rich people could do it. Now I wish I would have had the opportunity to take some science classes when I was in high school. I may have gone on to college if I had."

- Little girl during the parents and children Native community workshop, "Mama, can I make another cell?"

- "Superior demonstration for understanding!"

- "I enjoyed it very much. The activities kept you interested! You learn more with hands on project!

- "I'm going to tell my husband that I was a scientist today! And I DID IT!"

\section{Workshop Evaluation}

The overall GENA ${ }^{\circledR}$ workshops were evaluated excellent and very good (89.9\%) and 100\% responded that the objective increased their understanding.

\section{Discussion}

The GENA ${ }^{\circledR}$ faculty are very thankful to the Inupiaq elder who talked with us November 1, 2002 to let us know that he didn't know what a cell was. Such honest comments from 
participants are invaluable in helping the faculty focus on new areas that need to be developed or how objectives need to be modified to increase understanding. This objective is among one of the most fun for the participants and faculty alike.

\section{References}

Burhansstipanov, L., Bemis, L.T., Dignan, M. (2001). Native American cancer education: Genetic and cultural issues. Journal of Cancer Education, 16(3), 142-145.

Burhansstipanov, L., Bemis, L. T., Dignan, M. B. (2002). Native American recommendations for genetic research to be culturally respectful. Jurimetrics, 42, 149-57.

Burhansstipanov, L., Bemis, L. T., Dignan M. B., Dukepoo, F. (2001). Genetics education: Development of genetic education curriculum for Native American college and university students. Genetics, 158, 941-948.

Burhansstipanov, L., Bemis, L., Kaur, J. S., Bemis, G. (2005). Sample genetic policy language for research conducted with Native Communities. Journal of Cancer Education, 20(Suppl.), 52-57.

Dignan, M. B., Burhansstipanov, L., Bemis, L. (2005). Genetic education for Native Americans evaluation methodology and results. Genetics, 169, 517-521.

National Human Genome Research Institute. (2007). Bringing the genome revolution to the public. Retrieved November 10, 2006, from http://www.genome.gov/

Romero, F., Bemis, L. T., Dignan, M. and Burhansstipanov, L. (2001). Genetic research and Native American cultural issues. Journal of Women and Minorities in Science and Engineering, 7, 97106.

\section{Acknowledgements}

Genetic Education for Native Americans (GENA ${ }^{\circledR}$ ) was developed through the National Human Genome Research Institute (NHGRI), Ethical, Legal and Social Implications (ELSI) Section [grant \# HG01866; PI: L. Burhansstipanov], and through the Society for the Advancement of Chicanos and Native Americans in Sciences (SACNAS) subcontract with the NHGRI [Grant \# R25 HG003200-02S1 PI: M. L. Linton]. In addition, partial support for GENA ${ }^{\circledR}$ is from Mayo Clinic's Spirit of Eagles Community Network Programs [U01 CA 114609; PI: J.S. Kaur]. Special thanks to Joy Boyer, David Burgess, and Clifton Poodry for their continued support and assistance in helping the authors make new genetic information understandable in a culturally respectful manner for Native Americans and others.

URL for further information: Information about upcoming GENA ${ }^{\circledR}$ conferences will be included on the NACR website (http://www.NatAmCancer.org) beginning winter 2007.

\section{$\underline{\text { Author Information }}$}

Linda Burhansstipanov, MSPH, DrPH, CHES

Executive Director

Native American Cancer Research

3022 South Nova Road

Pine, CO 80470-7830

Ph.: 303-838-9359

Fax.: 303-838-7629

Native Cancer Survivors' Support Network: 1-800-537-8295

E-Mail: LindaB@,NatAmCancer.net

URL: http://www.NatAmCancer.org

Lynne T. Bemis, Ph.D.

Associate Professor of Medicine, Medical Oncology

University of Colorado Denver 


\section{L18-8403H}

12801 E. 17th Ave

Aurora, CO 80045

Ph.: 720-560-0278

Fax.: 303-724-3889

E-Mail: $\underline{\text { Lynne.Bemis@uchsc.edu }}$ 


\section{Appendix A}

\section{Directions for making the cell}

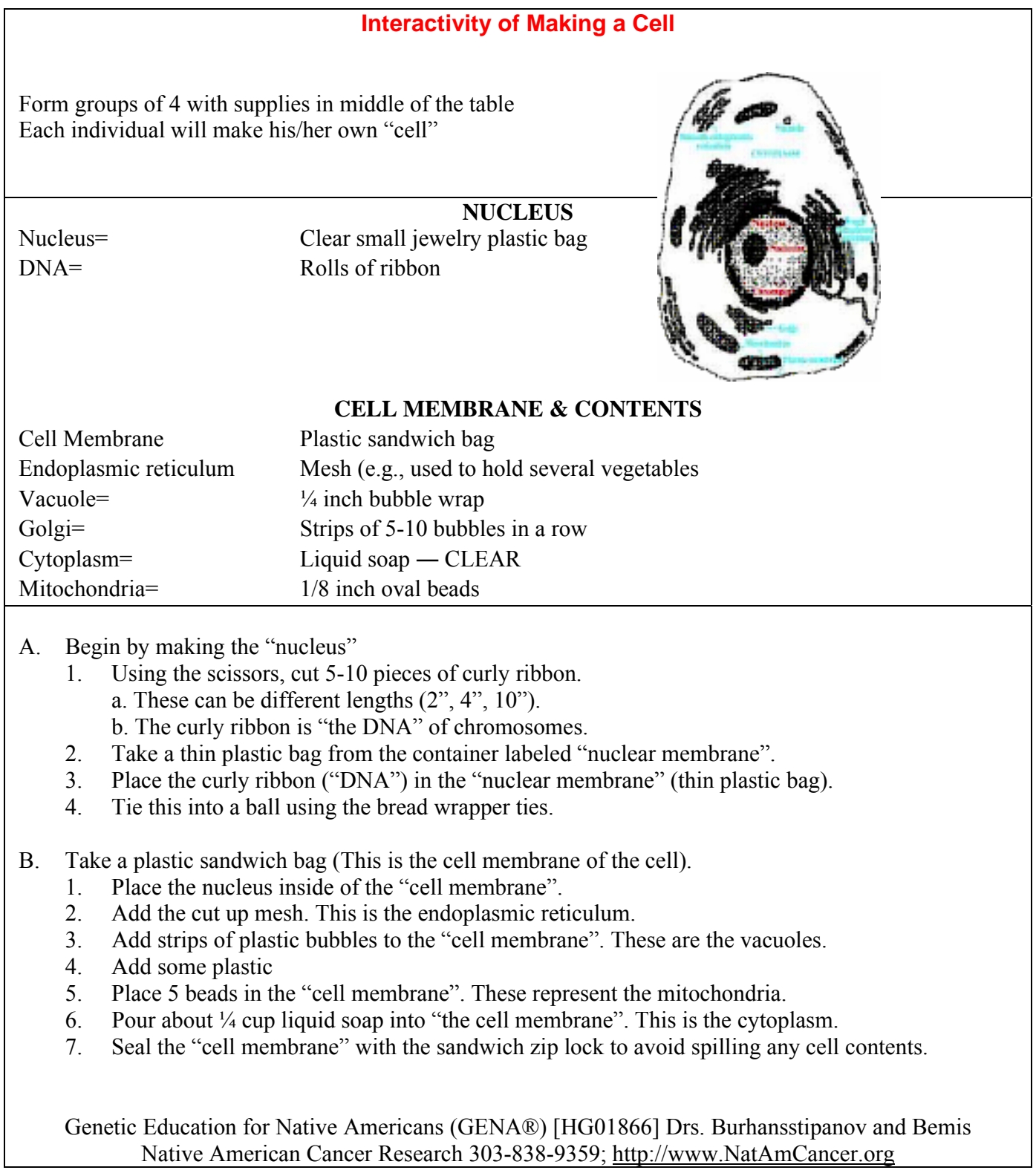




\section{Appendix B}

\section{CHES Objectives and Questions}

\section{CHES Objectives}

The health educator will be able to:

1. Identify materials that are used by participants to make the cell during the learning opportunity.

2. Identify how the GENA ${ }^{\circledR}$ objective 26 workshop was evaluated

\section{CHES Questions}

1. What material is used to represent the nucleus during the learning opportunity?
A. Plastic covered mesh
B. Small plastic jewelry bag
C. Sandwich bag
D. Beads

\section{Answer: B}

2. What material is used to represent the mitrochondria during the learning opportunity?
A. Plastic covered mesh
B. Small plastic jewelry bag
C. Sandwich bag
D. Beads

\section{Answer: D}

3. Which of the following was the Audience Response System (ARS) documented average increase from pre-workshop knowledge scores to post-workshop knowledge scores for GENA® objective $26 ?$
A. $\sim 14.5 \%$
B. $\sim 24.5 \%$
C. $\sim 47.5 \%$
D. $\sim 77.2 \%$

\section{Answer: C}

